\title{
Islam, islamofobija i Zapad: suprotstavljeni pogledi i društvena stvarnost
}

DOI: 10.11567/met.31.3.4

UDK: 304(4:5)

297:32

$316.74: 2$

Pregledni rad

Primljeno: 20. 06. 2015.

Prihvaćeno: 18. 03. 3016.

Adila Pavelić

Prva tehnička škola Tesla, Zagreb

adila.pavelic@gmail.com

\section{Jadranka Čačić-Kumpes}

Odjel za sociologiju, Sveučilište u Zadru, Zadar

jcacic@unizd.hr

\begin{abstract}
SAŽETAK
U radu se pregledom različitih i često suprotstavljenih pogleda na odnos islama i Zapada nastoji pridonijeti njegovu boljem razumijevanju i osvjetljavanju islamofobije kao staroga, ali sve aktualnijega i po svemu relevantnoga društvenog problema. Nakon kratkoga povijesnog pregleda razumijevanja odnosa islama i Zapada i definiranja islamofobije razmatraju se suvremeni radovi koji se iz različitih perspektiva bave problematikom toga odnosa. Najprije se daje uvid u one radove zapadnih teoretičara koji o odnosu islama i Zapada govore u okviru ideje o srazu civilizacija, pri čemu se na islam često gleda kao na nemodernu religiju i kulturu čiji pripadnici odbacuju zapadnjačke vrijednosti poput demokracije, slobode i rodne ravnopravnosti. Nasuprot njima predstavljaju se radovi autora koji se svojom argumentacijom suprotstavljaju tim stereotipnim pogledima na islam. Među takvim su radovima i oni koji kritički progovaraju o islamofobiji u suvremenome zapadnom društvu, bilo da iznose rezultate znanstvenih istraživanja islamofobije ili da dokumentiraju dominantnu medijsku sliku islama koja perpetuira stereotipe, osobito poslije terorističkih napada na New York 2001. Naposljetku se zaključuje da bez obzira na provenijenciju radova koji govore o odnosu islama i Zapada i na vrstu njihove argumentacije oni najčešće islam i Zapad ponajprije tumače kao dva odvojena, zaokružena i na svojevrstan način nespojiva svijeta. Pritom se, smatraju autorice, ne pristupa esencijalistički i redukcionistički samo islamu, kao što bi se moglo pretpostaviti, nego i Zapadu, a odnos islama i Zapada pojednostavljuje se i shematizira.
\end{abstract}

KLJUČNE RIJEČI: islam, Zapad, Europa, imigracija, islamofobija

...koliko je lakše iznositi ratoborne tordnje s ciljem mobiliziranja kolektionih strasti nego promisliti, propitati, zaključiti s čime u stvarnosti imamo posla, o uzajamnoj povezanosti bezbrojnih života, kako »naših « tako $i$ »jihovih«.

Edward W. Said (2001: 13) 


\section{UVOD}

Od početne ideje o pisanju rada na temu islamofobije problem islamofobije postaje sve aktualnijim i dnevno sve rasprostranjenijim i većim. ${ }^{1}$ Utoliko se rad koji se usredotočuje na pregled međusobnog razumijevanja islama i Zapada i promišljanja njihova odnosa na različitim razinama, od teorijske do dnevnopolitičke, učinio relevantnim za bolje razumijevanje te stare pojave i relativno novog pojma. ${ }^{2}$

Islamofobija predstavlja društveni problem koji se nakon terorističkih napada 11. rujna 2001. slijedom događaja i posredovanjem medijâ iz lokalnoga pretvorio u globalni fenomen (usp. npr. Allen, 2010). ${ }^{3}$ Odgovor Zapada na terorističke napade bio je rječit - »rat protiv terora « nadrastao je nacionalne granice. No u sjeni straha od terora koji izazivaju islamski fundamentalisti nerijetko se zanemaruje da kritika njihova ekstremizma i pozivanja na islam dolazi iz islamskoga svijeta. $S$ time bi u vezi bilo zanimljivo utvrditi primjerice koliko je općoj populaciji na Zapadu poznata »Poruka iz Ammana", odgovor islamskoga svijeta na jednoobraznost s kojom i islamski fundamentalisti i mnogi njegovi zapadni kritičari prikazuju islam. Poruka je upućena ponajprije »kršćanskome zapadu « (Al Shalabi i Alrajehi, 2011) s namjerom da se islam prikaže objektivno, u skladu sa svojim izvornim učenjima i raznolikošću, te da pripomogne iskorjenjivanju predrasuda prema islamu. ${ }^{4}$ Jednako tako, valjalo bi imati na umu da strah od islamskih

1 Ovaj je rad u suatorstvu s mentoricom znatno prerađena verzija diplomskoga rada (Adila Pavelić, »Islamofobija u suvremenom svijetu: neki teorijski prijepori«) koji je obranjen na Odjelu za sociologiju Sveučilišta u Zadru u rujnu 2014.

2 O prikladnosti dovođenja u odnos islamskoga i zapadnoga svijeta, islama i Zapada, kategorija koje ne potpadaju pod isto klasifikacijsko načelo, moglo bi se opravdano raspravljati iz više razloga, ali to nadilazi namjeru ovoga rada. Budući da središnja tema nisu te kategorije pojedinačno ni njihov odnos, nego radovi koji su ih stavili u odnos, navest ćemo samo kako su one operacionalizirane za potrebe rada. Pod »islamom« se, s jedne strane, podrazumijeva svjetska monoteistička religija, a s druge vjerska zajednica koja nema točno određene geografske i/ili političke granice, a koja »okuplja « sve etničke skupine koje prakticiraju islam kao religiju (v. Hassan, 2000; Voll, 2004). »Zapad « se definira u geografskom i u kulturnom smislu, a polazeći od modernizacijskih procesa s početka 19. stoljeća koji su društveno, politički i gospodarski ponajprije oblikovali Sjevernu Ameriku i zapadnoeuropske zemlje i proširili se, unoseći promjene, diljem svijeta. Naposljetku, možda nije suvišno napomenuti slaganje s Edwardom Saidom, koji pojmove islama i Zapada često stavlja u navodnike kako bi naglasio svoj stav da je riječ o generalizacijama i apstrakcijama koje u sebi nose ideološke implikacije (v. Said, 1999).

3 Događaji koji su slijedili, primjerice eksplozija terora »Islamske države«, teroristički napadi islamskih fundamentalista u europskim gradovima i diljem svijeta i silina migracijske krize u Europi, svaki je na svoj specifični način pridonio širenju islamofobije.

4 Izvorno je riječ o izjavi jordanskoga kralja Abdulaha II. iz studenoga 2004. (http://ammanmessage.com/index.php?lang=ens) koju je između 2005. i 2006. potpisalo više od petsto 
fundamentalista nije prisutan samo na Zapadu i među zapadnjacima. Mnoga su istraživanja pokazala da većina muslimana diljem svijeta, a posebice oni na Bliskome istoku, zazire od fundamentalističkih islamskih organizacija, terorističkih skupina i nasilnih vladara u državama s većinskim muslimanskim stanovništvom (v. Esposito i Mogahed, 2007).

Unatoč tome stvarni strah od stvarnog terorizma islamskih fundamentalista koji dodatno potiče medijski senzacionalizam, učestalo demoniziranje islama i reakcije zapadnih, ponajviše, iako ne i jedino, desnih političara i medija prebacuju se s terorista na muslimanske imigrante. To se pojednostavljivanje i sklonost generaliziranju na cijelu muslimansku populaciju manifestira u širenju ksenofobije i islamofobije među stanovništvom na Zapadu, ${ }^{5}$ pa kad je riječ o odnosu islama i Zapada u suvremenom kontekstu, sve više ponovno oživljava osporavana teza koja se pripisuje američkome politologu Samuelu Huntingtonu o srazu civilizacija s početka devedesetih.

U svjetlu takva stanja čini se potrebnim stalno promišljati odnos zapadnih i islamskih društava, istraživati njihovu umnogome zajedničku povijest i sadašnjost te pokušati rasvijetliti problem islamofobije, koja je potpomognuta kako sve većim strahom tako i iskrivljenom predodžbom o muslimanima i islamu u javnosti, medijima, a ponekad i u stručnim tekstovima (usp. Sant'Angelo, 2004; Allen, 2010). Odatle potječe i namjera ovoga rada da ponudi kritički pregled radova autora koji govore o odnosu islama i Zapada. On počinje kratkim povijesnim uvidom u odnos islama i Zapada, a potom se usredotočuje na razumijevanje islamofobije kao društvene pojave i predmeta istraživanja. Slijedi selektivan uvid u suvremene znanstvene tekstove koji o islamu i o odnosu islama i Zapada govore iz različitih perspektiva - $\mathrm{u}$

znanstvenika iz 84 zemlje. Nakon sastanka na vrhu 2005., složili su se oko triju temeljnih točaka. Prvom se točkom definiraju zajednička načela svih osam tradicionalnih islamskih pravnih škola, drugom neophodna obilježja i uvjeti za donošenje legitimnoga pravnog mišljenja, legitimne fetve (i pritom upozorava na nelegitimnost »fetvi« kojima ekstremisti opravdavaju terorizam), a pod trećom se osuđuje praksa anatemiziranja i proglašavanja drugih nevjernicima (čime ekstremisti opravdavaju teror nad neistomišljenicima). Riječ je, kažu Al Shalabi i Alrajehi (2011), o globalnoj izjavi o umjerenom i tolerantnom islamu nakon koje je došao niz diljem svijeta prihvaćenih inicijativa za uspostavljanjem međukulturnog i međureligijskog dijaloga (v. npr. A Common World between Us and You, 2009).

Jedan od primjera organiziranja građana na osnovi islamofobnih stavova jest PEGIDA (Patriotische Europäer gegen die Islamisierung des Abendlandes /Patriotski Europljani protiv islamizacije Zapada/), čiji su se pristaše krajem listopada 2014. počeli okupljati svakog ponedjeljka u Dresdenu. Dok je na prvim prosvjedima bilo svega nekoliko stotina ljudi, sredinom prosinca 2014. bilo ih je petnaest tisuća, a nakon napada na Charlie Hebdo u siječnju 2015. broj je narastao na 25 tisuća (s prijetećim transparentom »Jučer Pariz, sutra Berlin «). Protesti kakve organizira PEGIDA proširili su se iz Dresdena diljem Njemačke i Europe (primjerice u Švicarsku, Češku, Španjolsku, Englesku, Škotsku i Norvešku), ali s manje uspjeha nego u Dresdenu. O pokretu v. npr.: Social Europe Report, 2015. 
jednima se islam i muslimane opisuje na pretežno stereotipiziran način, a u drugima se takvu pogledu pristupa kritički. Neki od autora govore iz pozicije insajdera iz islamske perspektive, drugi, također insajderski, kritički razmatraju zapadnjačku islamofobiju otjelovljenu u medijskoj slici islama na Zapadu, dok treći iznose rezultate znanstvenih istraživanja o muslimanima i njihovim stavovima. Naposljetku se problematizira uočena tendencija da se islam i Zapad interpretiraju kao odvojene, zatvorene i nekompatibilne kategorije i podsjeća na problem nedovoljnog poznavanja islama koji se nerijetko očituje u isticanju ekstremnih pojava i obilježja što se pripisuju njegovu okrilju.

\section{ISLAMOFOBIJA: KRATAK POVIJESNI PREGLED NJEZINIH KORIJENA, POKUŠAJA DEFINIRANJA I NJEZINE MANIFESTACIJE U SUVREMENOM DRUŠTVU}

Veze islama i Zapada sežu u daleku povijest. No o njihovu odnosu gotovo da nije moguće govoriti, a da se, prema mišljenju povjesničara Franca Cardinija, ne spomene sukob. Pod tim se sukobom najčešće misli na suprotstavljenost kršćanstva i islama kao dviju konkurentskih religija (Cardini, 2009: 9). Uvid u zapadnjačke srednjovjekovne poglede na islam, napominje primjerice Schwartz oslanjajući se na nalaze medijevalista Richarda Southerna, pokazuje da je od samih početaka riječ o nerazumijevanju i slaboj informiranosti jer se znanje o islamu od 7. pa sve do 11. stoljeća i križarskih pohoda temeljilo na potpunim dezinformacijama. Sve je to dovelo do toga da se predodžba većine kršćana o islamu svodila na metaforičnu sliku kuge koju je Bog poslao na zemlju, na sliku vražje tvorevine, krivovjerja i slijepog obožavanja. Džamije su opisivane kao hramovi mnogoboštva ili bezbožnosti, simboli nastranih seksualnih praksi (Southern, prema Schwartz, 2010: 21), a Muhamed kao antikrist, podmukli mađioničar, nasilni spletkar i slično (Geisser, 2004). Takvu ideju »opasnih muslimana« kršćanski je Zapad, smatra politolog Vincent Geisser, dugo promicao u svrhu ojačavanja vlastitog identiteta te postizanja ideološkoga i religijskog jedinstva. Naime Geisser tvrdi da u 15. stoljeću Osmanlije nisu predstavljali prijetnju Zapadu u vjerskome, nego ponajprije u geopolitičkom smislu (Geisser, 2004: 38). Tad se, osobito nakon turske opsade Carigrada 1453., kad se Osmansko Carstvo s islamom kao dominantnom religijom našlo nadomak kršćanske zapadne Europe, napominje Wilfried Hofmann, još više produbila podjela na »islamski Istok«i »kršćanski Zapad« (Hofmann, 2008: 8). Erik Love 
podsjeća da se predodžba o Orijentu ${ }^{6}$ kao o opasnome »drugom « nastavila i u razdoblju europskoga kolonijalizma, kad se on zapadnjacima nije činio samo egzotičnim nego i iracionalnim i inferiornim u odnosu na zapadnu civilizaciju, zbog čega mu je potrebno spasenje (Love, 2009: 409-410). Edward Said smatra da je Europa preko francuskih i britanskih kolonijalnih sila nastavila upravljati dojmom o islamskim zemljama sve do kraja Drugoga svjetskog rata (usp. Love, 2009; Said, 1999), pa i poslije njega.

$S$ druge strane, nerijetko se zanemarivala (i još se zanemaruje) dobro poznata činjenica da je u Osmanskome Carstvu preko miletskoga sustava službeno na svojevrstan način prihvaćen religijski pluralizam. Postojala su tri nemuslimanska mileta, koja su obuhvaćala pripadnike nemuslimanskih religija: pravoslavne, ostalih kršćanskih religija i židovske (Stamatopoulos, 2006: 253). Taj se oblik religijskog i kulturnog pluralizma manifestirao i na upravnoj razini, pa su nemuslimanske vjerske vlasti autonomno, izvan službene državne kontrole, upravljale svojim vjernicima. ${ }^{7}$ Takav je sustav održavan stoljećima, sve dok se Turska nije modernizirala i postala sekularnom državom. Valja dodati i to da se zanemaruje, kad se u suvremenim prilikama razmatra islam kao stran i dalek, da je Osmansko Carstvo dugi niz godina oblikovalo, kao što podsjeća i Derek Bryce (2013), geopolitičku i kulturnu stvarnost jugoistočne Europe. Na tom se području nalaze sekularne države s većinskim muslimanskim stanovništvom koje su nastale na rubovima nekadašnjih višeetničkih carstava, dijelom na njihovim ruševinama, a dijelom raspadom socijalističke Jugoslavije.

Unatoč činjenici da je islam raznolik i da po mnogome nije uvijek ni tako dalek, slika o njemu kao o religiji čije su vrijednosti suprotstavljene zapadnima i koja predstavlja prijetnju i opasnost Zapadu traje stoljećima (usp. Cardini, 2009: 9). Dakako, ne treba smetnuti s uma ni to da se od sredine 20. stoljeća odvilo mnoštvo događaja koji su pripomogli oživljavanju slike o nasilnome, opasnom islamu kao prijetnji zapadnom društvu i njegovim vrijednostima. ${ }^{8}$ Pritom se međutim nerijetko zanemaruje da bi pri njihovu

6 U to su se vrijeme pod »Orijentom« podrazumijevali cijela Indija i Levant (Said, 1999: 10). U suvremenom kontekstu, poglavito u Americi, pod Orijentom se uglavnom misli na područje Bliskog istoka (Love, 2009: 410).

7 Vjerska zajednica nije se nužno poklapala s etničkom, pa je ovaj sustav vjerske autonomnosti postupno, a osobito u vrijeme buđenja nacionalnih identiteta u 19. stoljeću, ostavio za sobom zbrku kad je riječ o poimanju državljanstva, religije i etničnosti (v. ČičakChand, 1999: 269).

8 Osim već spomenutih dramatičnih događaja s početka 21. stoljeća, valja spomenuti i Iransku islamsku revoluciju 1979., ubojstvo egipatskog predsjednika 1981., libanonsku desetogodišnju talačku krizu, aferu oko Salmana Rushdieja, islamističku pobunu u Alžiru te dugogodišnje sukobe šijita i sunita diljem Bliskog istoka (Cesari, 2009: 161). 
razumijevanju valjalo razlikovati islam od islamizma, što je islamsko, a što islamističko, tj. ono što pripada islamu kao svjetskoj religiji, a što islamizmu kao vjersko-političkom radikalnom pokretu (usp. npr. Khader, 2015; MacDonald, 2015). Unatoč tome što islamski fundamentalisti predstavljaju manjinu muslimanske populacije, oni svojim ekstremizmom i okrutnošću u borbi protiv pozapadnjenja promiču iskrivljenu sliku islama (v. Ahmed, 2004; Al Shalabi i Alrajehi, 2011). Zbog toga se nerijetko lakše zanemaruje i zaboravlja da većina muslimana doživljava islam na individualan način, da ga prakticira kao umjerenu religiju i da, kako pokazuju istraživanja, većina muslimana nije antizapadnjački nastrojena i njeguje životne stilove koji uvelike nalikuju na one nemuslimanskih zapadnjaka (v. Esposito i Mogahed, 2007; Schwartz, 2010; Hockenos, 2011). Tom zanemarivanju činjenica pridonose i mediji, koji često u prvi plan stavljaju ekstremnu stranu koja sebe deklarira braniteljicom islama. Drugim riječima, širi se strah od islama, tj. jača islamofobija.

Po svemu, strah, mržnja ili neprijateljski stav prema islamu, odnosno prema mnogim ili svim muslimanima, zasnovan na predrasudama, daleko je stariji od samoga pojma islamofobije, konceptualiziranoga, smatra se, 1997. u Velikoj Britaniji, u Runnymedeovu ${ }^{9}$ izvještaju o antimuslimanskoj diskriminaciji (Cesari, 2009: 152; Allen, 2010; Bleich, 2011: 1583). ${ }^{10}$ Pokušavajući pridonijeti boljem razumijevanju islamofobije, »te trajne pojave koja brzo napreduje«, britanski sociolog Chris Allen (2010: 4) vrlo podrobno podsjeća na taj utjecajni dokument koji je pod naslovom »Islamophobia: A Challenge for Us All« izvijestio o britanskoj društvenoj stvarnosti i koji počinje opisom obilježjâ islamofobije, »ružne riječi za ružnu stvarnost « (The Runnymede Trust, 1997: iii), kako u uvodniku kaže Gordon Conway, voditelj Komisije o britanskim muslimanima i islamofobiji koja je sastavila izvještaj. Prvo opisano obilježje islamofobije jest to da se islam doživljava monolitnim i statičnim, a ne raznolikim i dinamičnim, što je posljedica esencijalističkog pogleda na islam, koji zanemaruje njegovu pluralnost u geografskome, povijesnom i kulturnom smislu i vodi prema uopćavanju koje naposljetku svakog muslimana opisuje kao fundamentalista. Sljedeće je da se islam doživljava kao ono »drugo« i drugačije, izolirano i nespojivo s europskim (britanskim itd.). Iz percipirane oprečnosti normi proizlazi i treća

9 Runnymede je nezavisni analitički centar (think tank) koji se bavi problemom rasne nejednakosti u Ujedinjenom Kraljevstvu (v. http://www.runnymedetrust.org/about.html).

10 Iako postoji konsenzus da konceptualizacija islamofobije počinje s Runnymedeovim izvještajem iz 1997., sam je izraz nešto stariji. U tom izvještaju on je datiran u kasne osamdesete godine 20. stoljeća, ali Allen primjerice navodi da se izraz islamofobija spominje još 1925. u knjizi Étiennea Dineta i Slimana ben Ibrahima L'Orient vu de l'Occident (Allen, 2010: 5). 
značajka islamofobije - viđenje islama kao inferiornoga u odnosu na Zapad. Islamu pripisane primitivnost, iracionalnost, neorganiziranost, nasilnost, seksističnost, mizoginost te sklonost spletkama, barbarstvu i represiji u suprotnosti su s civiliziranošću, racionalnošću, velikodušnošću, sofisticiranošću, prosvijećenošću i efikasnošću koje se pripisuju Zapadu. Stoga se, nadalje, $\mathrm{u}$ islamu ne vidi partner, nego neprijatelj, a muslimane se opisuje kao manipulativne i neiskrene, one koji se vjerom koriste kao oružjem. Sva ta obilježja dovode i do toga da se muslimanska kritika Zapada odbacuje bez razmatranja, da se podrazumijeva prirodnost antimuslimanskih stavova, te do opravdavanja »rasne « diskriminacije prema muslimanima (The Runnymede Trust, 1997; usp. Allen, 2010: 69-73).

Iakoje diskriminacija usko povezana s islamofobijom (v.npr.Sant'Angelo, 2004), Eric Bleich ne uključuje ju primjerice u definiciju islamofobije jer je ne smatra njezinim obilježjem, nego njezinom izravnom posljedicom (Bleich, 2011: 1587). Razmatrajući koncepciju islamofobije, Bleich kaže da se ona pojavila kao politički pojam, ali da se sve češće upotrebljava u analitičke svrhe, kao komparativni koncept u društvenim znanostima (Bleich, 2011: 1582). Iako se pojam islamofobije udomaćio, kaže Bleich, malo je suglasja oko njegova značenja. ${ }^{11}$ Stoga on nakon uvida $u$ definicije islamofobije drugih autora nudi vlastitu i određuje ju kao »neselektivne negativne stavove ili emocije prema islamu ili muslimanima«(Bleich, 2011: 1585). Smatra da je moguće govoriti o različitim stupnjevima islamofobije koji se razlikuju po učestalosti, dosljednosti i snazi izražavanja islamofobnih stavova (Bleich, 2011: 1587).

Iako islamofobija predstavlja globalni problem, ona je posebno izražena u Europi, u kojoj je i prije posljednjega imigracijskog vala u drugom desetljeću 21. stoljeća bio koncentriran najveći broj muslimanskih imigranata. Prema podacima istraživačkoga centra Pew, procjenjuje se da je 2009. u Europi živjelo približno 38 milijuna muslimana, ${ }^{12}$ ponajviše imigranata,

11 Ni Ujedinjeni narodi nisu ponudili konačnu definiciju ili značenje islamofobije (Allen, 2010: 17).

12 Oko dva posto svjetske muslimanske populacije živi u Europi. Muslimani čine oko pet posto ukupne europske populacije, računajući imigrante i autohtonu muslimansku populaciju, koja je i većinsko stanovništvo u trima europskim zemljama - u Albaniji i na Kosovu muslimani čine apsolutnu (osamdeset odnosno devedeset posto), a u Bosni i Hercegovini relativnu većinu (četrdeset posto) (v. http://www.pewforum.org/2009/10/07/ mapping-the-global-muslim-population14/\#map1). Valja napomenuti da ti podaci ne uključuju Tursku, koja se uglavnom smatra azijskom zemljom unatoč geografskom položaju na rubu Europe i dugogodišnjim nastojanjima da pristupi Europskoj uniji. Taj se ulazak neprekidno osporava između ostaloga i argumentom o nepremostivim kulturnim i vjerskim razlikama, što Ahmet Yükleyen smatra kontraproduktivnim esencijalizmom koji zanemaruje dinamičnost i unutar same Europe i islama (Yükleyen, 2009: 117). 
na koje se gleda kao na »unutarnjeg uljeza« (Poynting i Mason, 2007: 69), a koji su vrlo često socioekonomski marginalizirani, nezaposleni i slabo obrazovani (Cessari, prema Kayaoğlu, 2012: 613). Jedna od posljedica sve uočljivije muslimanske prisutnosti u Europi bila je nelagoda zbog mogućeg narušavanja predodžbe o stabilnome europskom identitetu i njegovu kršćanskom temelju (Moreno, 2010: 74). Sve je to poduprlo sklonost islamofobiji, osobito (i očekivano) u radikalnim desnim političkim krugovima (usp. Green, 2012: 338-339; Y1lmaz, 2012), a u novije vrijeme sve češće i među liberalnijim strankama (Abu Sway, 2005; Hockenos, 2011). Osim političke i medijske upotrebe islamofobije njezine različite manifestacije moguće je, osobito nakon newyorškog 11. rujna 2001., upozoravaju mnogi autori, uočiti u mnogim europskim državama u različitim društvenim sferama (v. npr. Sant' Angelo, 2004; Geisser, 2004; Love, 2009: 412). ${ }^{13}$

U tome smislu, na njemačkome primjeru, Heidi Mescher (2008) govori o važnosti društvenoga konteksta pri izražavanju islamofobnih stavova. U kontekstu rasprava o njemačkoj državnoj politici s početka 21. stoljeća u kojima se naglašava golema muslimanska različitost koja predstavlja prijetnju njemačkim vrijednostima, istraživanja o diskriminaciji u Njemačkoj pokazala su, podsjeća Mescher, da osobe porijeklom iz Turske u velikoj mjeri i/ili više od pripadnika drugih imigrantskih etničkih skupina (primjerice etničkih Nijemaca, Aussiedlera, i Grka) primjećuju diskriminaciju. Rezultati njezina istraživanja, unatoč ograničenjima, ${ }^{14}$ potvrđuju znanja o čimbenicima koji su povezani s izraženošću predrasuda, poput političkog opredjeljenja ispitanika (njemačkih policajaca), njihova zadovoljstva poslom i položajem na njemu. Posebno se naglašava važnost sinergije kvalitete kontakta s pripadnicima muslimanske zajednice, interkulturnih znanja te atmosfere na radnome mjestu i u lokalnoj zajednici koja može pripomoći smanjivanju islamofobije (Mescher, 2008).

13 Islamofobija se ogleda i u zakonima i propisima nekolicine europskih vlada, primjerice u onima koji muslimankama zabranjuju nošenje hidžaba i/ili burki (Abu Sway, 2005; Khiabany i Williamson, 2008; Hockenos, 2011). Slično je i kad je riječ o otporu izgradnji džamija. U Švicarskoj je primjerice 2009. donesena odluka kojom je zabranjena izgradnja minareta (Hockenos, 2011: 26), a u Slovačkoj, u kojoj nema nijedne džamije, zabilježen je sustavan otpor (Moreno, 2010). Još su drastičniji primjeri islamofobije povećan broj zločina iz mržnje prema muslimanima, broj uništenih džamija te fizičkih i verbalnih napada na muslimane u mnogim europskim zemljama (Sant'Angelo, 2004; Love, 2009; Geisser, 2004).

14 Ograničena konkluzivnost istraživanja Heidi Mescher kad je riječ općenito o islamofobnim stavovima u Njemačkoj proizlazi iz usko definirana predmeta istraživanja. Naime nastojalo se steći uvid u povezanost iskustva unutar radne atmosfere policijskih službenika te njihovih stavova i sklonosti u ponašanju prema muslimanima u Njemačkoj (v. Mescher, 2008). 
Ono što zasigurno ne pridonosi smanjivanju islamofobije jest jačanje antiliberalnih ideologija i političkih pokreta diljem Europe, za koje Aleksandra Ålund i Carl-Ulrik Schierup kažu da su oblikovani na integralističkoj filozofiji koja »zaziva 'naciju', 'zajednicu', 'kulturu', religiju, 'boju', 'krv' ili 'podrijetlo' kao esencijalističke poveznice društva « (Ålund i Schierup, 2011: 57). Moglo bi se reći da se takav trend osobito odražava na životne prilike muslimanskih imigranata. Europljani prema muslimanima pokazuju nepovjerenje i zazor (Pollack, 2010), a oni se nerijetko osjećaju ugroženima i smatraju žrtvama diskriminacije (Mythen, Walklate i Khan, 2013). U takvu se društveno-povijesnom kontekstu počela revitalizirati i osporavana teza o srazu civilizacija.

\section{O ODNOSU ISLAMA I ZAPADA U ZNANSTVENOJ I STRUČNOJ LITERATURI, PUBLICISTICI I MEDIJIMA}

Huntington je početkom devedesetih nagovijestio novo razdoblje svjetske politike u kojem osnovni izvor sukoba neće biti ideološke ni ekonomske, nego kulturne naravi, a sukobit će se, smatra, pripadnici »nacija i skupina različitih civilizacija « (Huntington, 1993: 22) ${ }^{15}$ Najveći bi se sukobi, prema njemu, trebali dogoditi uzduž kulturnih rasjedina između pojedinih civilizacija za koje kaže da su posljedica stoljetnih procesa, pa ne mogu samo tako nestati. Sve intenzivniji kontakti različitih civilizacija u sve tješnjem svijetu, predviđa Huntington, dovest će do sukoba zato što su etničke i kulturne identifikacije od velike važnosti za pojedince i narode, a kulturne su razlike istovremeno velike i nepomirljive. On tvrdi da će, zbog revitalizacije religije i pojava fundamentalizma, glavno izvorište neslaganja i sukoba biti povijesno duboko ukorijenjene religijske razlike. Poticaj pak religijskome fundamentalizmu u nezapadnim civilizacijama i procesu odzapadnjenja vidi u dominaciji zapadne civilizacije u ekonomskome, vojnom i političkom smislu (Huntington, 1993: 26-27). Kao jednu od linija sukoba Huntington očekuje onu, davno uspostavljenu, između zapadne i islamske civilizacije jer »vojno međudjelovanje između Zapada i islama«, kaže, traje već stoljećima, pa nema puno izgleda da će se situacija samo tako promijeniti (Huntington, 1993: 31-32). Zato bi, kao i zbog drugih potencijalnih linija sukoba, prema Huntingtonu, kratkoročni zadaci Zapada trebali biti s jedne strane povezivanje i čvršća suradnja unutar vlastite civilizacije kako bi se spriječilo unutarnje sukobe, a s druge ograničavanje vojnog razvoja u konfucijevskim

15 Huntington navodi sedam do osam civilizacija za koje smatra da će njihovi međuodnosi oblikovati svijet. To su »zapadna, konfucijevska, japanska, islamska, hinduistička, slavensko-pravoslavna, latinoamerička i moguće afrička civilizacija (Huntington, 1993: 25). 
i islamskim državama te podržavanje onih skupina unutar drugih civilizacija koje se poistovjećuju sa zapadnim vrijednostima i onih međunarodnih institucija koje zastupaju interese Zapada. Dugoročno bi Zapad, zaključuje Huntington, trebao napraviti sve što je u njegovoj moći da bi održao svoj dominantni status u svijetu jer zapadna je civilizacija moderna civilizacija i pozapadnjivanje jest njezin interes. Naposljetku, on ipak ne očekuje stvaranje jedinstvene civilizacije, pa smatra potrebnim upoznavanje drugih i utvrđivanje zajedničkih obilježja, što bi trebalo unaprijediti koegzistenciju različitih civilizacija (Huntington, 1993: 49).

Sintagmu »sraz civilizacija « koja se najčešće pripisuje Huntingtonu zapravo je prvi upotrijebio u svome razmatranju odnosa islama i Zapada povjesničar i orijentalist Bernard Lewis (1990). ${ }^{16}$ Temeljna razlika, smatra on, potječe iz različitih društveno-povijesnih okolnosti u kojima su se razvijale dvije velike univerzalne religije - kršćanstvo i islam. Tijekom povijesti snažni su religijski sukobi unutar kršćanstva, tvrdi Lewis, stvorili prostor za doktrinu odvajanja crkve od države kao preduvjeta obuzdavanja religijske nasilne netolerancije. $S$ druge strane, razmimoilaženja $u$ islamu nisu bila tako snažna da bi iznjedrila sličnu doktrinu (Lewis, 1990: 56). Sekularizacija i ostali modernizacijski procesi koji su počeli na Zapadu preslikavali su se u druge dijelove svijeta i nigdje nisu bili, smatra Lewis, manje uspješni nego u islamskim zemljama. Budući da, kako on kaže, veliki broj Bliskoistočnjaka smatra da su zapadni utjecaji u svakom pogledu donijeli nešto negativno siromaštvo u gospodarstvu, tiraniju u politici i neuspjeh u socijalnoj politici - ne čudi ga što su mnogi od njih spremni "poslušati glasove koji im govore da su stari islamski putevi najbolji i da im je jedini spas da odbace poganske inovacije reformatorâ i prihvate pravi put koji je Bog propisao za svoj narod «(Lewis, 1990: 59). U suvremenom odnosu Zapada i islama riječ je stoga, prema Lewisu, o pravom srazu civilizacija, koji je »možda iracionalan, ali je zasigurno povijesna reakcija na drevno suparništvo s našim židovsko-kršćanskim naslijeđem, našom sekularnom sadašnjicom i njihovim širenjem diljem svijeta« (Lewis, 1990: 60). Taj sraz pripisuje fundamentalizmu, koji, kako sam kaže, nije jedino što obilježava islamsku tradiciju. ${ }^{17}$ Budući da je ta tradicija pluralna, nada se da će njezin otvoreniji i tolerantniji dio, onaj koji

16 Unatoč tome što mu nitko ne osporava dobro poznavanje islama, mnogi se suprotstavljaju njegovim interpretacijama i gledištima (v. npr. http://english.al-akhbar.com/node/14409; http://www.americanthinker.com/articles/2013/03/bostom_interview_what_went_ wrong_with_bernard_lewis.html). Dio kritika rezultat je njegova političkog angažmana, smatrajući da je pridonio srazu civilizacija savjetujući američkoga predsjednika Georgea W. Busha u njegovoj politici prema Bliskom istoku.

17 Ovdje se ne čini naodmet napomenuti da Lewis govori o islamskom fundamentalizmu kao dijelu islamske tradicije, a ne kao o islamizmu. 
je stvorio velika dostignuća islamske civilizacije u prošlosti, prevagnuti i u budućnosti. Dotad bi, preporučuje Lewis, muslimanima trebalo prepustiti da sami utvrde put kojim će krenuti. I islam i Zapad trebali bi unaprijediti međusobno poznavanje, poznavanje drugih religijskih i političkih kultura i poštovanje prema njima. Slične zaključne poruke obaju zastupnika ideje o srazu civilizacija nisu oslobođene svojevrsnog paternalizma s kojim se u ime Zapada gleda na islam jer i Huntington i Lewis, čini se, modernizaciju razumiju kao vesternizaciju, pri čemu poželjni rezultat susreta različitih civilizacija više sliči asimilaciji onih drugih, »nezapadnih «, ili barem njihovoj koegzistenciji u tvrdome kulturnorelativističkom smislu. U tome smislu i Said upućuje kritiku Huntingtonu, koji, prema njegovu mišljenju, na civilizacije, kulture i identitete gleda pojednostavljeno, razumijevajući ih kao zasebne, zatvorene jedinice koje se međusobno ne dodiruju i nemaju veze jedna s drugom (Said, 1999: 437). ${ }^{18}$

Iako i Huntington i Lewis i sami, svaki na svoj način, relativiziraju tezu o srazu civilizacija, koja je osim spomenute Saidove doživjela i brojne druge kritike znanstvene $\mathrm{i}$ ine javnosti, ${ }^{19}$ ta je zavodljiva i nikad potpuno napuštena sintagma ponovo oživjela slijedom intenziviranja terorističkih napada islamskih fundamentalista od početka 21. stoljeća. Stoga se važnim čini iznijeti i one teorijske i empirijske doprinose koji se na svojevrstan način odupiru negativnom stereotipiziranju islama i polariziranju odnosa Zapada i islama.

Eugenio Chahuan (2005) i Ervand Abrahamian (2003) primjerice smatraju da su streotipiziranju islama pridonijeli američki mediji jer su kao glavnoga krivca za islamistički terorizam navodili nedostatak slobode i demokracije na Bliskom istoku, a sve u svrhu opravdavanja američkih napada na Afganistan i Irak u sklopu »rata protiv terora«. Kako se islam u javnome prostoru sve češće počeo povezivati s terorizmom, povećalo se i izražavanje islamofobnih stavova (Abrahamian, 2003; Ahmed, 2004). ${ }^{20}$

18 Said osuđuje generaliziranje i kritizira Huntingtonovu tendenciju da sve muslimane opisuje kao jednu osobu, zanemarujući činjenicu da je riječ o milijunima ljudi raspršenih po čitavom svijetu, koji govore raznovrsne jezike i posjeduju jednako raznovrsne tradicije i povijesti. On smatra da umjesto »sraza civilizacija « u modernom svijetu dolazi do »sraza u definiranju«. Prema Saidu, prije nego što se počne govoriti o neminovnom srazu civilizacija, treba definirati svaku od tih civilizacija, koje i same nose u sebi vlastite različitosti i unutarnje sukobe (Said, 1996).

19 U tom je smislu Dag Strpić primjerice opomenuo na polemiku koja je u francuskome časopisu Commentaire objavljena već 1994. (v. http://www.nacional.hr/feljton-kako-su-povijest-pocele-oblikovati-nezapadne-civilizacije/).

20 Na temelju uvida u američki tisak Abrahamian kaže da se u njemu poslije 11. rujna 2001., implicitno ili eksplicitno, promicalo ideje o kulturnom sukobu i o zapadnoj civilizaciji kojoj prijete »drugi«, odnosno muslimani (Abrahamian, 2003: 529), te da je javnim mnije- 
Kuvajtski politolog Shafeeq N. Ghabra (2004) tvrdi da na Zapadu prevladava pojednostavljena slika islama, koji se gotovo instinktivno povezuje s nasiljem i terorizmom, bez daljnjih objašnjenja i razmatranja različitih povijesno-kulturnih čimbenika. ${ }^{21}$ On smatra da bi Zapad trebao zagrebati ispod površine i ponovno promisliti o izvorima istočnjačke ljutnje, protesta i terorističkih akcija. Suvremeni terorizam, naglašava, kolektivni je problem koji bi se trebao detaljno istraživati uzimajući u obzir različite povijesnokulturne čimbenike. On smatra da ga se, iako je riječ o ekstremnom obliku nasilja koje provodi manjinska skupina u muslimanskom narodu, ipak može protumačiti kao izraz akumuliranog nezadovoljstva muslimanskog naroda u cijelosti i kao posljedicu dugogodišnje represije, diktature i tiranije, manjka ljudskih prava i korupcije, tj. događaja iz novije povijesti koji su imali snažan negativan utjecaj na muslimanski svijet (Ghabra, 2004; usp. Hamdi, 2013). Osim toga, dodaje Mohammad Samiei, Zapad bi trebao više kritički pristupiti razumijevanju demokracije u vlastitim društvima i načina na koji svoje dugo demokratsko iskustvo prenosi ili želi prenijeti u ostale dijelove svijeta (Samiei, 2010: 1157).

Vjerojatno najpoznatiji i najutjecajniji autor koji je upozoravao na to da su zapadne zemlje, vodeći se vlastitom zapadnocentričnošću, stvorile izrazito stereotipnu sliku islamskih zemalja, kultura i ljudi jest Edward Said. ${ }^{22}$ Mišljenja je da se pojam islama u suvremenome svijetu počeo rabiti djelomično kao fikcija, a djelomično kao ideološka oznaka te da se njime ponajmanje označuje religija (Said, prema Jeknić 2006: 300). Takva slika o islamu, smatra Said, odgovara Zapadu jer njome opravdava nastavak svoje kulturne i ekonomske ekspanzije. Prema njegovu mišljenju, Americi je moderna civilizirajuća misija poslužila kao izlika za iscrpljivanje naftnih izvora, održavanje političke i kulturne dominacije, razaranje i terorizam u takvoj mjeri kakvu, smatra, »muslimanski terorizam« neće nikada doseći (Said, 2005: 212). On se kritički osvrće na zapadne stručnjake za islam i Bliski istok koji, po njegovoj tvrdnji, ignoriraju svaki pokušaj muslimana da uspostave dijalog ili

njem u SAD-u počela prevladavati izrazito stereotipna negativna slika islama (Abrahamian, 2003: 538).

${ }^{21}$ Kao jedan od mogućih uzroka tog nasilja rijetko se spominju napetosti i nezadovoljstvo u muslimanskim zemljama zbog slučaja Palestine, a još rjeđe utjecaj Zapada u ključnim »istočnim« sukobima, od razdoblja Osmanskog Carstva pa sve do početka 21. stoljeća (Ghabra, 2004; usp. Samiei, 2010; Hamdi, 2013).

22 Edward Said rođen je u Jeruzalemu u vrijeme kad je on pripadao Palestini, s roditeljima kršćanima emigrirao je u Egipat, školovao se i radio na Zapadu. U svojem je vlastitome multikulturnom iskustvu, kaže Rade Kalanj, sažeo i reflektirao naslijeđe kolonijalizma i smisao postkolonijalnosti (Kalanj, 2001: 44). Zalagao se i za oformljivanje suverene države Palestine, nerijetko kritizirajući upletenost Zapada na prostoru Izraela (v. npr. Said, 2007). 
intelektualnu razmjenu (Said, 2000: 308-309) i iza čijeg se znanstvenog autoriteta oblikuje iskrivljena slika o islamu u zapadnoj javnosti. Takvu sliku podupiru u velikoj mjeri i mediji, pa je sve to zasjenilo Saidovo nastojanje da pokaže isprepletenost naroda i kultura od početka njihova postojanja (Said 2001: 13) i promiče ideju o važnosti njihova kontakta.

Koliko može biti utjecajna povezanost znanosti i medija i medijsko prenošenje mišljenja stručnjaka i/ili interpretiranje znanstvenih radova, pokazalo je oživljavanje teze o srazu civilizacija nakon rujna 2001. Pisac i novinar Paul Hockenos (2011) navodi niz primjera antimuslimanskih izjava javnih osoba, među kojima i izjavu francuskoga filozofa i jednog od najcjenjenijih europskih autora Bernard-Henrija Lévyja da je muslimanski veo »poziv na silovanje«. Osobito utjecajnim za islamofobno raspoloženje u Njemačkoj Hockenos je procijenio odjek knjige Deutschland schafft sich ab: Wie wir unser Land aufs Spiel setzen (Njemačka ukida samu sebe: kako smo svoju zemlju izložili opasnosti) ekonomista i socijaldemokrata Thilla Sarrazina. U njoj se Sarrazin poziva na znanstveno istraživanje koje ga je dovelo do zaključka da muslimanski imigranti predstavljaju opasnost za njemački kulturni identitet. Oni, kaže, iskorištavaju njemački sustav socijalne skrbi, ali se ne žele niti su se sposobni integrirati u Njemačkoj. ${ }^{23}$ Popularnosti knjige nisu naškodili znanstveni protuargumenti, a ona je bila tolika da je stišala početnu političku kritiku. Hockenos primjećuje ono što je iznenadilo mnoge, a to je da je islamofobna retorika počela dolaziti s političke ljevice, i to ona utjecajnih pojedinaca. Stoga osim političke desnice i već spomenutih Lévyja i Sarrazina Hockenos posebno apostrofira niz britanskih, danskih, francuskih i njemačkih intelektualaca i političara s ljevice. Među njima izdvaja, nazivajući je »majkom njemačkoga feminističkog pokreta«, Alice Schwarzer, koja opisuje islam kao mizoginičnu i mizantropsku vjeru što poriče univerzalnost ljudskih prava. Time, smatra Hockenos, Schwarzer pridonosi argumentima konzervativne desnice, čijoj su se politici i propisima i ona kao i ostali liberalni intelektualci desetljećima suprotstavljali (v. Hockenos, 2011: 24).

Poput Hockenosa i Green (2012) upozorava na antimuslimanske izjave europskih političara (poput Geerta Wildersa, vođe Slobodarske stranke u Nizozemskoj, i pokojnog Jörga Haidera, nekadašnjeg člana austrijske Slo-

23 O popularnosti Sarrazinove knjige govori činjenica da je tijekom prve godine prodano više od 1,5 milijuna primjeraka (http://www.focus.de/magazin/debatte/focus-leserdebatte-schadet-sich-die-spd-mit-ihrem-sarrazin-kurs_aid_623031.html). Dvije godine nakon njezina izlaska, 2012., dvojica novinara, Pitt von Bebenburg i Matthias Thieme, objavila su 2012. knjigu Deutschland ohne Ausländer: Ein Szenario, suprotstavljajući se antiimigrantskoj atmosferi argumentima zasnovanima na statističkim podacima te razgovorima sa znanstvenicima i stručnjacima. 
bodarske stranke). On podsjeća na ksenofobičnu izjavu britanskog premijera Davida Camerona, koji je 2011. konstatirao da je multikulturalizam kriv za slabljenje kolektivnoga britanskog identiteta (Green, 2012: 340), i na spremnost medija da olako nagađaju o odgovornosti muslimana za terorističke napade (na primjeru norveških medija $\mathrm{u}$ »Breivikovu slučaju«) (Green, 2012: 337).

Naposljetku, ne treba zaboraviti ni karikature proroka Muhameda objavljene u danskom dnevniku Jyllands-Posten 2005., čija strukturna složenost, smatra Simon Weaver (2010), izaziva različita tumačenja. Njih je, prema njemu, moguće shvatiti kao kritiku islamskog fundamentalizma, kao bogohuljenje koje vrijeđa muslimane i napada islam, kao islamofobne i rasističke stereotipe ili kao satiru koju treba braniti prema načelu slobode govora. Iz različitih tumačenja mogu proizaći i različite reakcije, a one se često, smatra Weaver, ograničavaju na jedno od spomenutih mogućih tumačenja (Weaver, 2010: 680), a očitovale su se, kao što bi se moglo reći i za kasniji primjer francuskoga satiričnog magazina Charlie Hebdo, ponajviše i najočiglednije $\mathrm{u}$ dvije krajnosti - obrani prava na slobodu govora s jedne $\mathrm{i}$ terorizmu islamskoga fundamentalizma s druge strane.

Oslanjajući se na višeslojno tumačenje kulturnih znakova, u ovom slučaju dvanaest objavljenih karikatura proroka Muhameda, Weaver u nastavku objašnjava svoju koncepciju »tekućeg rasizma« kojom se označuje, prema analogiji s Baumanovom koncepcijom tekuće modernosti, rasizam čija struktura nije tako čvrsta kao ona tradicionalnog rasizma. Daljnja bi istraživanja, smatra Weaver, mogla razotkriti društvene i povijesne razmjere tekućega rasizma kao strukturno nove, ali po svome sadržaju stare pojave (Weaver, 2010: 678-679). Da bi se islamofobiju moglo nazvati antimuslimanskim rasizmom, smatraju i Sabine Schiffer i Constantin Wagner (2011: 77). Riječ je, kažu, o složenoj pojavi koja nadilazi diskurs »protuimigracijskog rasizma «, argumentirajući to činjenicom da antimuslimanski stavovi potječu iz daleke prošlosti, a budući da je meta religijska, a ne »rasna« ili etnička skupina, može se govoriti o novom obliku rasizma (Schiffer i Wagner, 2011: 79). ${ }^{24}$

S obzirom na činjenično postojanje islamskoga fundamentalizma, koji u zapadnim kulturama vidi glavne neprijatelje i veliku opasnost za očuvanje identiteta, njegovu globalnu prisutnost i strah koji šire njime motivirani teroristički napadi, čini se važnim potkrijepiti već spomenutu konstataciju da je riječ o skupinama koje ne čine većinu muslimanske populacije te da

24 Allen (2010) također smatra da se islamofobiju može shvatiti kao ideologiju sličnu rasizmu (usp. Kayaoğlu, 2012). 
većina muslimana ima negativne stavove prema terorizmu. To potvrđuje Gallupovo šestogodišnje istraživanje provedeno u 35 država s većinskim muslimanskim stanovništvom na nekoliko desetaka tisuća ispitanika. Pokazalo se da $35 \%$ ispitanika izražava pozitivne stavove prema SAD-u i ne podržava terorizam usmjeren na SAD, da njih 55\% ima negativne stavove o SAD-u, ali ne podržava terorizam, a da skupinu »radikalnih muslimana « koji izražavaju negativne stavove o SAD-u i podržavaju terorizam čini sedam posto ispitanika (Esposito i Mogahed, 2007: 48). Istraživanja provedena u Njemačkoj na koja se referira Hockenos (2011) pokazuju da se velika većina muslimana ne identificira isključivo kroz religiju, nego se određuje i preko društvenoga položaja, regionalnog porijekla i zanimanja, a samo je sedam posto onih duboko religioznih privrženo patrijarhalnim tradicijama i životu u etničkim enklavama. Novija istraživanja pokazuju da je životni stil većine europskih muslimana sličniji onome nemuslimanskih Europljana (Hockenos, 2011: 26). Kad je riječ o odnosu europskih muslimana prema islamu, Jocelyne Cesari napominje, navodeći primjer novih generacija muslimana u Francuskoj, da mnoge analize pokazuju tendenciju individualizacije religijske prakse, ${ }^{25}$ ali da se one razlikuju u interpretaciji posljedica individualizacijskih procesa. Naime postavlja se pitanje vodi li individualizacija liberalizaciji prakse ili izraženijem fundamentalizmu (Cesari, 2009). Cesari smatra da nije moguće razumjeti što se događa s muslimanima bez komparativnog uvida u promjene koje se zbivaju u drugim religijskim skupinama.

Među komparativne uvide svakako pripada analiza vrijednosnih orijentacija, o čemu govore Inglehart i Norris na temelju skupnih rezultata dvaju Svjetskih istraživanja vrijednosti (World Values Survey). Prvo je istraživanje provedeno 1995. i 1996., a drugo između 2000. i 2002. u 75 država. Rezultati tih istraživanja omogućili su Inglehartu i Norris usporedbu vrijednosti i uvjerenja u muslimanskim i nemuslimanskim zemljama. Ona je pokazala da se povijesno-religijsko naslijeđe odražava na suvremene vrijednosti, ali da se razlika između muslimanskih i židovsko-kršćanskih društava ne očituje, kako je pretpostavio Huntington, u političkoj sferi. Naime utvrdili su da ispitanici i u jednim i u drugim društvima (s izuzetkom Pakistana) demokraciju smatraju najboljim oblikom vlasti, ali da se raskorak očituje kad je riječ o rodnoj ravnopravnosti, stavovima o razvodu, pobačaju i pravima homoseksualaca te o povezanosti religije i politike (Inglehart i Norris, 2003:

25 To, naravno, ne znači da je takav individualizam prisutan samo među muslimanima koji žive na Zapadu. I muslimani u islamskome svijetu, kaže Cesari, kritički propituju svoj odnos prema tradiciji i religiji (Cesari, 2009: 152). 
64). ${ }^{26}$ Budući da se privrženost društva rodnoj ravnopravnosti i liberalizaciji spolnosti smatra pouzdanim indikatorom ostvarivanja načela tolerancije i jednakosti u pojedinom društvu, Inglehart i Norris zaključuju da se, unatoč tome što velika većina ispitanika u muslimanskim društvima demokraciju smatra poželjnom, nameće pitanje njezine održivosti u njihovim društvima. Činjenicu da su ispitanici u većini muslimanskih zemalja stavovski skloniji poduprijeti usku povezanost politike i religije od ispitanika u zapadnim društvima Inglehart i Norris ne smatraju u tolikoj mjeri kulturnom razlikom između Zapada i islama koliko jazom »između Zapada i mnogih drugih manje sekularnih društava širom svijeta«, a to potkrepljuju i podacima po pojedinim zemljama (Inglehart i Norris, 2003: 66). Budući da rezultati istraživanja pokazuju da problem ne leži u nedostatku želje za demokracijom, nego u uvjetima za njezino ostvarenje, oni smatraju da nije dovoljno uspostavljanje demokratskih vlasti, nego stvarno poticanje razvoja ljudskih potencijala u muslimanskim zemljama (Inglehart i Norris, 2003: 70). K tome upozoravaju da »problem demokracije« na Bliskom istoku ne proizlazi nužno iz same prirode islama i njegovih načela, nego je vjerojatno rezultat represivnih politika muslimanskih vođa koji odbijaju implementirati demokraciju bez obzira na želje svojih naroda (v. Norris i Inglehart, 2002). Takav zaključak podupiru nalazi Marka Tesslera, koji pokazuju da lokalna gospodarska struktura (u odnosu s međunarodnim političkim i gospodarskim poretkom) ili pak otpor prema političkim promjenama vladajućih struktura otežavaju jačanje demokracije $\mathrm{u}$ arapskome svijetu (Tessler, prema Inglehart, 2002: 225).

\section{ZAKLJUČAK}

Na temelju uvida u razmatranja odnosa islama i Zapada može se reći da se, bez obzira na polazišta i argumentaciju pojedinih autora, islam i Zapad uglavnom shvaća kao dvije zasebne i nerijetko suprotstavljene kategorije, kao dva odvojena svijeta koja gotovo da nemaju dodirnih točaka. Takvo gledište ne obilježava samo tvrdi kulturni relativizam, koji se može uočiti u Lewisovoj i Huntingtonovoj koncepciji sraza civilizacija, i politizaciju javnoga mnijenja perpetuiranjem straha od islamskog fundamentalizma na

26 U zapadnim društvima primjerice $82 \%$ ispitanika podržava rodnu ravnopravnost, a u muslimanskima ih je 55\%. Zapadna su društva tolerantnija i kad je riječ o pravu na pobačaj, razvodima i homoseksualnosti. $\mathrm{K}$ tome, dok se u muslimanskim društvima snažno suprotstavlja stavovima da nereligiozni političari nisu prikladni vođe i da je bolje da javne službe obavljaju osobe sa snažnim religijskim uvjerenjima $39 \%$ ispitanika, u zapadnim ih je društvima 62\% (Inglehart i Norris, 2003: 64). 
globalnoj razini i od gubitka primjerice europskoga kulturnog identiteta zbog udjela muslimanskih imigranata u Europi, nego je ono u velikoj mjeri prispodobivo i njihovim kritičarima. Bryce (2013) pripisuje ga primjerice i Saidu, koji je, prema njegovu mišljenju, zapostavljajući teorijske implikacije islamske prisutnosti preko Osmanskoga Carstva u Europi, pridonio percepciji islama (i Istoka) i Zapada kao odvojenih i zatvorenih kategorija.

Nadalje, čak i kad se priznaju raznolikost i višeslojnost islama, predodžba o njemu nerijetko se stereotipizira, što stvara bipolarnu sliku nemodernoga, iracionalnog i nasilnog islama s jedne i civiliziranoga, slobodnog i razvijenog Zapada s druge strane (npr. Lewis, 1990, 1997, 2002; Huntington, 1993). Na taj se način promiče esencijalistički pogled ne samo na islam nego i na Zapad (usp. Said, 2001). Time se ne reducira samo muslimanski identitet na nekoliko njegovih odlika nego i »zapadnjački« (usp. Norris i Inglehart, 2002).

Takva reducirana slika prema kojoj je islam inherentno nekompatibilan sa Zapadom, poduprta islamskim fundamentalizmom i terorističkim napadima te neadekvatnim i neusklađenim odgovorom Europske unije na migracijsku krizu, potiče islamofobiju. Taj pak relativno novi pojam podložan je propitivanju, pa bi se, kao što predlažu neki autori, umjesto njega mogao upotrijebiti i pojam novog oblika rasizma, bilo da je riječ o tekućemu (Weaver, 2010) ili antimuslimanskome rasizmu (Schiffer i Wagner, 2011) ili pak kulturnome rasizmu kako ga definira Giddens (2007).

Naposljetku, istraživanja su pokazala (v. Inglehart, 2002; Norris i Inglehart, 2002; Inglehart i Norris, 2003; Mescher, 2008; usp. npr. Cesari, 2009; Hockenos, 2011) da treba biti oprezan s uopćavanjima i da je za razumijevanje tako složenog odnosa kao što je onaj različitih kultura (ili civilizacija) potrebno mnogo intelektualne otvorenosti, sveobuhvatnih znanja i složenih pristupa. Ipak, s obzirom na usložnjavanje društveno-povijesnih prilika i dugotrajno stereotipiziranje islama na Zapadu, nije se teško složiti sa zabrinutošću britansko-pakistanskog teoretičara etničnosti Tariqa Modooda (2015), koji je, povlačeći paralelu s Du Boisovim predviđanjem da će boja kože biti razdjelnica tijekom 20. stoljeća, zaključio da se čini da slijedi stoljeće u kojem će ona biti između islama i Zapada. 


\section{LITERATURA}

Abrahamian, E. (2003). The US media, Huntington and September 11, Third World Quarterly, 24 (3): 529-544, doi: 10.1080/0143659032000084456.

Abu Sway, M. (2005). Islamophobia: Meaning, Manifestations, Causes, Palestine-Israel Journal of Politics, Economics and Culture, 12 (2-3): 15-23.

A Common World between Us and You (2009). Jordan: The Royal Aal al-Bayt Institute for Islamic Thought, http://www.acommonword.com/downloads/CW-BookletFinal-v6_8-1-09.pdf (23. 07. 2014.).

Ahmed, A. S. (2004 [2003]). Islam pod opsadom. Sarajevo: Libris.

Al Shalabi, J. i Alrajehi, M. B. (2011). The Amman Message: Arab Diplomacy in the Dialogue of Civilizations, Journal of US-China Public Administration, 8 (12): 1375-1392.

Allen, C. (2010). Islamophobia. Farnham: Ashgate.

Ålund, A. i Schierup, C.-U. (2011). The end of Swedish exceptionalism? Citizenship, neoliberalism and the politics of exclusion, Race $\mathcal{E}$ Class, 53 (1): 45-64, doi: $10.1177 / 0306396811406780$.

Bleich, E. (2011). What Is Islamophobia and How Much Is There? Theorizing and Measuring an Emerging Comparative Concept, American Behavioral Scientist, 55 (12): 1581-1600, doi: 10.1177/0002764211409387.

Bryce, D. (2013). The Absence of Ottoman, Islamic Europe in Edward W. Said's Orientalism, Theory, Culture E Society, 30 (1): 99-121, doi: 10.1177/0263276412456562.

Cardini, F. (2009 [1999]). Europa i islam. Zagreb: Sandorf i Hasanbegović.

Cesari, J. (2009). Islam in the West: From Immigration to Global Islam, Harvard Middle Eastern and Islamic Review, 8: 148-175.

Chahuan, E. (2005). An East-West Dichotomy: Islamophobia, Palestine-Israel Journal of Politics, Economics and Culture, 12 (2-3): 47-52.

Čičak-Chand, R. (1999). Islam, etničnost i država: Balkan, Migracijske teme, 15 (3): 263287.

Esposito, J. L. i Mogahed, D. (2007). Who Speaks for Islam? What a Billion Muslims Really Think. New York: Gallup Press.

Geisser, V. (2004). Islamophobia in Europe: from the Christian anti-Muslim prejudice to a modern form of racism, u: I. Ramberg (ur.). Islamophobia and its Consequences on Young People: European Youth Centre Budapest, 1-6 June 2004. [Strasbourg]: Council of Europe, 36-46.

Ghabra, S. N. (2004). The tension between East and West, u: Common Ground News Service, December 2004, http://www.commongroundnews.org/article. php?id=2465\&lan=en\&sp=0 (23. 07. 2014.).

Giddens, A. (2007 [2001]). Sociologija. Zagreb: Nakladni zavod Globus.

Green, T. H. (2012). Who Speaks for Europe's Muslims? The Radical Right Obstacle to Dialogue, CrossCurrents, 62 (3): 337-349, doi: 10.1111/j.1939-3881.2012.00245.x.

Hamdi, T. K. (2013). Edward Said and Recent Orientalist Critiques, Arab Studies Quarterly, 35 (2): 130-148, doi: 10.13169/arabstudquar.35.2.0130.

Hassan, R. (2000). Sociology of Islam, u: E. F. Borgatta i R. J. V. Montgomery (ur.). Encyclopedia of Sociology. Second Edition, Vol. 5. New York: Macmillan Reference USA, 2937-2953.

Hockenos, P. (2011). Europe's Rising Islamophobia, The Nation, May 9, 22-26. 
Hofmann, M. W. (2008). A Short History of European East West Relations, Arches Quarterly, 2 (1): 8-10.

Huntington, S. P. (1993). The Clash of Civilizations?, Foreign Affairs, 72 (3): 22-49, doi: $10.2307 / 20045621$.

Inglehart, R. (2002). Islam, gender, culture, and democracy: Introduction, International Journal of Comparative Sociology, 43 (3-5): 224-228, doi: 10.1177/002071520204300301.

Inglehart, R. i Norris, P. (2003). The True Clash of Civilizations, Foreign Policy, 135: 6370, doi: $10.2307 / 3183594$.

Jeknić, R. (2006). Kulturni imperijalizam Zapada u djelu Edwarda W. Saida, Migracijske i etničke teme, 22 (3): 289-308.

Kalanj, R. (2001). Kulturni imperijalizam. Kritički pogledi Edwarda Saida, Socijalna ekologija, 10 (1-2): 43-58.

Kayaoğlu, T. (2012). Three takes on Islamophobia, International Sociology, 27 (5): 609-615, doi: 10.1177/0268580912452360.

Khader, J. (2015). Repeating Fundamentalism and the Politics of the Commons: The Charlie Hebdo Tragedy and the Contradictions of Global Capitalism, Islamophobia Studies Journal, 3 (1): 12-28.

Khiabany, G. i Williamson, M. (2008). Veiled bodies - naked racism: culture, politics and race in the Sun, Race \& Class, 50 (2): 69-88, doi: 10.1177/0306396808096394.

Lewis, B. (1990). The Roots of Muslim Rage, The Atlantic Monthly, 266 (3): 47-60.

Lewis, B. (1997). The West and the Middle East, Foreign Affairs, 76 (1): 114-130, doi: $10.2307 / 20047913$.

Lewis, B. (2002). What Went Wrong?, The Atlantic Monthly, 289 (1): 43-45.

Love, E. (2009). Confronting Islamophobia in the United States: Framing civil rights activism among Middle Eastern Americans, Patterns of Prejudice, 43 (3-4): 401-425, doi: 10.1080/00313220903109367.

MacDonald, E. G. (2015). Muslims in Canada: Collective Identities, Attitudes of Otherment and Canadian Muslim Perspectives on Radicalism, Islamophobia Studies Journal, 3 (1): 44-61.

Mescher, H. (2008). Policing and Islamophobia in Germany: The Role of Workplace Experience, International Journal of Conflict and Violence, 2 (1): 138-156.

Modood, T. (2015 [2003]). Muslims and European multiculturalism, u: openDemocracy, https://www.opendemocracy.net/tariq-modood/muslims-and-europeanmulticulturalism\%20 (15. 10. 2015.).

Moreno, L. (2010). Fearing the Future: Islamophobia in Central Europe, The New Presence, 12 (3): 73-80.

Mythen, G., Walklate, S. i Khan, F. (2013). 'Why Should We Have to Prove We're Alright?': Counter-terrorism, Risk and Partial Securities, Sociology, 47 (2): 383-398, doi: $10.1177 / 0038038512444811$.

Norris, P. i Inglehart, R. (2002). Islam \& the West: Testing the 'Clash of Civilizations' Thesis, https://www.hks.harvard.edu/fs/pnorris/Acrobat/Clash\%20of\%20Civilization. pdf (15. 10. 2015.).

Pollack, D. (2010). Germans are much less tolerant of Muslims, u: Westfälische WilhelmsUniversität Münster - Exzellenzcluster »Religion und Politik «, https://www.unimuenster.de/imperia/md/content/religion_und_politik/aktuelles/2010/12_2010/pm_ en_zur_pressekonferenz_02.12.2010.pdf (15.07. 2014.). 
Poynting, S. i Mason, V. (2007). The resistible rise of Islamophobia: Anti-Muslim racism in the UK and Australia before 11 September 2001, Journal of Sociology, 43 (1): 61-86, doi: 10.1177/1440783307073935.

Said, E. W. (1996). The Myth of the Clash of Civilizations, http://site.iugaza.edu. ps/ rareer/archives/1841 (03. 07. 2014.).

Said, E. W. (1999 [1978]). Orijentalizam. Zagreb: Konzor.

Said, E. W. (2000). Reflections on Exile and Other Essays. Cambridge: Harvard University Press.

Said, E. W. (2001). The Clash of Ignorance, The Nation, October 22, 11-13.

Said, E. W. (2005 [2004]). Od Osla do Iraka. Zagreb: V.B.Z.

Said, E. W. (2007 [1999]). Nepripadanje: memoari. Zagreb: V.B.Z.

Samiei, M. (2010). Neo-Orientalism? The relationship between the West and Islam in our globalised world, Third World Quarterly, 31 (7): 1145-1160, doi: 10.1080/01436597.2010.518749.

Sant'Angelo, F. (2004). The Council of Europe and the work against Islamophobia: Existing instruments and standards, u: I. Ramberg (ur.). Islamophobia and its Consequences on Young People: European Youth Centre Budapest, 1-6 June 2004. [Strasbourg]: Council of Europe, 29-35.

Schiffer, S. i Wagner, C. (2011). Anti-Semitism and Islamophobia - new enemies, old patterns, Race \& Class, 52 (3): 77-84, doi: 10.1177/0306396810389927.

Schwartz, S. (2010). Islamophobia: America's New Fear Industry, http://www. islamicpluralism.org/documents/1640.pdf (25. 06. 2014.).

Social Europe Report (2015). Understanding Pegida in Context. London: Social Europe Friedrich-Ebert-Stiftung.

Stamatopoulos, D. (2006). From Millets to Minorities in the 19th-Century Ottoman Empire: an Ambiguous Modernization, u: S. G. Ellis, G. Hálfadanarson i A. K. Isaacs (ur.). Citizenship in Historical Perspective. Pisa: Edizioni Plus - Pisa University Press, 253-273.

The Runnymede Trust (1997). Islamophobia: A Challenge for Us All. Report of the Runnymede Trust Commission on British Muslims and Islamophobia.

Voll, J. O. (2004). Islam and islamic, u: Richard C. Martin (ur.). Encyclopedia of Islam and the Muslim World. New York: Macmillan Reference USA, 359-360.

Weaver, S. (2010). Liquid Racism and the Danish Prophet Muhammad Cartoons, Current Sociology, 58 (5): 675-692, doi: 10.1177/0011392110372728.

Y1lmaz, F. (2012). Right-wing hegemony and immigration: How the populist far-right achieved hegemony through the immigration debate in Europe, Current Sociology, 60 (3): 368-381, doi: 10.1177/0011392111426192.

Yükleyen, A. (2009). Compatibility of 'Islam' and 'Europe': Turkey's EU Accession, Insight Turkey, 11 (1): 115-131. 


\title{
Islam, Islamophobia and the West: Opposing Views and Social Reality
}

\author{
Adila Pavelić, Jadranka Čačić-Kumpes
}

\begin{abstract}
SUMMARY
Through reviewing different and often opposing views on the relationship between Islam and the West, the paper aims to offer a better understanding of this relationship, and of Islamophobia as an old, yet increasingly actual and in many respects relevant social problem. A short historical overview of the understanding of the relationship between Islam and the West, and various definitions of Islamophobia, are followed by examination of some recent works that from different perspectives deal with the issue. Firstly, is given insight into the works written by Western theorists who describe the relationship between Islam and the West within the framework of the idea of the clash of civilizations while, at the same time, labeling Islam often as a non-modern religion and culture whose members reject Western values such as democracy, freedom and gender equality. In contrast to them are introduced the authors whose argumentation opposes stereotypical views of Islam; among them are also those that critically address Islamophobia in today's Western society, either by presenting results of their research on Islamophobia or by documenting the dominant media image of Islam, which has been perpetuating stereotypes, especially in the aftermath of the terrorist attacks on New York in 2001. Lastly, it is concluded that, regardless of the origin of works dealing with the relationship between Islam and the West or of the type of their arguments, they more often than not interpret Islam and the West primarily as two separate, self-contained and in itself incompatible worlds. In doing so, the authors here argue, they employ an essentialist and reductionist approach not only to Islam - as it might be assumed - but also to the West, while the relationship between Islam and the West is simplified and schematized.
\end{abstract}

KEY WORDS: Islam, the West, Europe, immigration, Islamophobia 